\title{
Food labels: consumer's information or consumer's confusion
}

\author{
Sylvette Monier-Dilhan* \\ INRA, Observatoire du Développement Rural, INRA Occitanie, Castanet Tolosan, France
}

Received 21 November 2017 - Accepted 26 January 2018

\begin{abstract}
This paper synthesizes findings of published research on the impact of food labels on consumers' willingness to pay and focuses on the consumers' rationales when deciding to purchase organic food. The first issue refers to one aspect of the proliferation of quality labels in the agro-food sector: the coexistence of two signs on one product and the consequences of this coexistence on the value of each sign. In the context of the competition between national brands and private labels through public quality labels, it has been shown that the willingness to pay for a quality sign decreases when it is combined with another one on the same product. The second concern is a two-fold issue: the characterization of "organics food consumers" in terms of socio-demographics characteristics and consumers' purchasing motives. The more consistent result is that consumers with higher levels of education are more likely to purchase organic products. The three main reasons for buying organic products are considerations related to health, product quality, and environmental protection. The proliferation of signs about quality is a topical issue related to the emergence of sustainability issues that highlight labels linked to agro-ecological practices. The question of the effectiveness of the informational role of labels remains relevant.
\end{abstract}

Keywords: food labels / willingness to pay / organic food / consumer behaviour

\begin{abstract}
Résumé - Les signes de qualité dans le secteur alimentaire: information ou confusion pour le consommateur. Dans un contexte de profusion des signes de qualité dans le secteur agroalimentaire, ce papier synthétise des résultats concernant l'impact de ces signes sur la disposition à payer des consommateurs et les motivations des acheteurs d'aliments issus de l'agriculture biologique, marché en fort développement. La première question renvoie à un aspect de la multiplication des labels de qualité : la coexistence de deux signes de qualité sur un même produit et les conséquences sur la valeur de chaque signe. Dans le contexte de concurrence entre marques nationales et marques de distributeurs via les labels publics, il a été montré que la disposition à payer pour un signe de qualité diminue lorsqu'il est combiné, sur le même produit, avec un autre signe de qualité. Le second point a un double enjeu: d'une part, la caractérisation sociodémographique des «consommateurs d'aliments issus de l'agriculture biologique » et, d'autre part, leurs motivations d'achat. Le résultat commun aux nombreuses études est que les consommateurs dont le niveau d'étude est élevé sont plus susceptibles d'acheter des produits biologiques. Par ailleurs, les principales raisons d'acheter des produits biologiques sont liées à la santé, à la qualité du produit et à la protection de l'environnement. La prolifération des signes de qualité est un enjeu d'actualité vue l'émergence de problématiques de durabilité mettant en avant des labels liés aux pratiques agroécologiques. La question de l'efficacité du rôle informationnel des labels reste pertinente.
\end{abstract}

Mots clés : signes de qualité / disposition à payer / alimentation biologique / comportement des consommateurs

\section{Introduction}

There is a large product differentiation in most sectors of the economy. Faced with this situation, consumers need

\footnotetext{
*Correspondence: sylvette.monier@inra.fr
}

information in order to choose the product that best matches their expectations. The need for information depends on the kind of quality attribute the consumer looks for. For search attributes, consumers can determine the product's quality before they buy it by examining the product (e.g., wine colour), in which case, a label is useless; for experience attributes, consumers cannot determine a product's quality until they use 
Table 1. Sample description.

\begin{tabular}{lllllll}
\hline & \multicolumn{5}{c}{ Product } \\
\cline { 2 - 7 } & Yogurt & Eggs & Cooked ham & Milk & Camembert cheese & Dry cured ham \\
\hline Label & Organic & Organic & Label rouge & Organic & PDO & PGI \\
Number of observations & 135004 & 52549 & 49294 & 46359 & 25715 & 10873 \\
\hline
\end{tabular}

it (gustative attribute); for credence attributes, consumers cannot determine a product's quality even after consuming it (sustainable production), in which case, information is essential. In the presence of imperfect information, economic agents look for corrections tools. Labelling plays a growing role along the gradient from search attributes to credence attributes (Caswell and Modjuszka, 1996). The EU promotes four types of food quality labels, namely, Protected Designation of Origin, Protected Geographical Indications, Traditional Speciality Guaranteed and organic farming, which typically inform on credence attribute (the geographical origin of food production, production based on a tradition or on a method of production). In France, there is also the official quality certification 'Label rouge'. Consumer concerns are not confined to geographical indications or high quality. Buying decisions are driven by food safety concerns, health motivations, fair trade, environmental impact, animal welfare, and the absence of genetically modified organisms. For these credence attributes, the consumer's confidence in the certifying organization plays an essential role. Teisl and Roe (1998) point out the importance of a clear and standardized labelling policy.

The use of credible labels allows firms to signal the presence of specific attributes and create the potential for premiums based on this signal. Many articles have studied the effects of label information on consumers' willingness to pay for food attributes (Fair Trade characteristics by Vlaeminck and Vranken, 2015; Sustainability by Grunert et al., 2014; ecolabels, GM food labels, U.S. state agricultural product labels and European Protected Geographical Indication labels by McCluskey and Loureiro, 2003). Another facet of the literature addresses the profile of buyers of organic products. We illustrate these two issues with recent results from the economic literature: the effect of having multiple labels on the same product on the consumer's willingness to pay and the growing importance of organic food products.

\section{Willingness to pay}

Among the proliferation of private brands, retailers' brands (brand sold under a retailer's brand) have experienced strong growth, with a market value share approximately $30 \%$ in 2014. ${ }^{1}$ Competition between these brands and the national brands (sale to the consumer through multiple retailers) is often through public quality labels. What is the impact of the overlay of two quality labels on the same product in terms of willingness to pay? To answer this question, we consider the addition of a store brand/national brand (low quality/high

\footnotetext{
${ }^{1}$ LSA 06/05/2015 https://www.lsa-conso.fr/les-mdd-peuvent-ellesrebondir,208999.
}

quality) to products carrying a public quality label (sign of high quality). This coexistence creates a double vertical ${ }^{2}$ differentiation: a differentiation between national brands (associated with high quality) and store brands (associated with low quality) and a differentiation based on the presence or absence of a public quality label. How do store brands exploit public quality labels to compete with national brands? When public quality labels coexist with a signal of low quality, how do they remain attractive to consumers? In order to answer this question, we adopt a hedonic approach to estimating consumers' willingness to pay. We measure the implicit prices of public quality labels and those of brands (national and store brands) as well as the interactions between the two. See Hassan and Monier-Dilhan (2006) for a complete presentation of the model and data used.

The products we examine are milk, yogurt, eggs and cooked ham, camembert cheese and dry cured ham. The products selected reflect the diversity of public quality labels: Protected Designation of Origin (PDO) and Protected Geographical Indication (PGI), the organic label and the Label Rouge. PDO and PGI inform the consumer about the product's origin and guarantee that the product has certain characteristics. The organic label guarantees that the product is made under strict production standards-in particular, that certain pesticides and artificial fertilisers are not used in the production process and that certain practices, such as food ionization, are excluded. The Label Rouge concerns the intrinsic quality of the products. We use Kantar WordPanel database for the year 2000. Table 1 gives a description of the sample.

Results show that leading national brands are, without exception, better valorized than store brands. Except for eggs, the willingness to pay for the public label is higher for store brand products than for national brand products. These results hold when considering two kinds of national brands; leader national brands and secondary national brands. In terms of brand (national brand/store brand), the willingness to pay decreases when we move from leader national brand to secondary national brand then to store brand. In terms of public label, the willingness to pay for a given label is always weaker on the leading national brand than on the other two types of brands. The comparison between secondary national brands and store brands concerning the value of public quality labels does not reveal any hierarchy. This result reflects the diversity

\footnotetext{
${ }^{2}$ Two products are vertically differentiated when all consumers would prefer one to the other if they were sold at same price, whereas they are horizontally differentiated when at the same price some consumers will buy one and some will buy the other, depending on their pReferences
} 
of secondary national brands, which may have different levels of reputation.

The selling products carrying a public quality label under a store brand does not lead to a devaluation of the public label: producers' reluctance to commercialize public quality label products under a store brand is not justified. Another interpretation of the result is that the use of these signals by retail firms is a strategy that enables them to compete successfully against national brands. Indeed, this strategy enables store brands to improve their perceived quality. Such a strategy helps retailers build a positive reputation that will enable them to win the loyalty of consumers, a crucial element in the power balance between producers and retailers.

The rationale behind the reduction in WTP when there is a multiplicity of labels on one same product could be interpreted as decreasing returns to scale of quality labels. It also could be seen as an illustration of dilution effect (Hotaling et al., 2015) according to which consumers have difficulty managing multiple pieces of information affecting the value assigned to labels.

In the context of the expanding market for organic food products, a recurring question in the literature concerns the reasons behind consumers' (un)willingness to pay for organic food.

We address this question by some examples in the next section.

\section{Consumers considering organic food}

Although organic food sales still account for a small percentage of the overall food market, the organic sector is one of the fastest growing food markets in developed countries. In France, the sale of organic products, which have doubled between 2010 and 2016, generate $3 \%$ of the turnover for food products. $^{3}$

Empirical researchers have approached many questions related to the consumption of organic food products, including consumer valuation of organic food and developing a statistical "profile" of a typical organic food consumer in terms of motivations as well as in terms of socio-demographic characteristics. The more consistent result is that consumers with higher levels of education are more likely to purchase organic products (O'Donovan and McCarthy, 2002; Magnusson et al., 2003; Wier et al., 2008; Monier-Dilhan et al., 2009; Dettmann and Dimitri, 2010; Dimitri and Dettmann, 2012). There is no consensus about the impact of other households' socio-economic characteristics. Wier et al. (2008) and Loureiro et al. (2001) conclude that the propensity to purchase organic products tends to increase with the presence of young children in a household. Durham (2007) finds that such a presence has no impact, whereas Zepeda and Li (2007) come to the conclusion that the presence of young children reduces the probability of buying organic food. Income similarly yields mixed findings. Higher income households are more likely to purchase organic produce (Loureiro et al., 2001), but others find that income is unrelated to the likelihood of buying organic food (Durham, 2007; Monier-Dilhan et al., 2009).

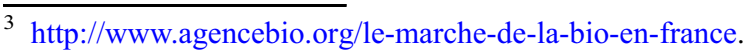

According to consumer surveys, price is the most common barrier to purchasing organic products in Europe and in the U. S. From empirical studies, Thompson and Kidwell (1998), Bunte et al. (2007) and Monier-Dilhan et al. (2009) find that marginal variations in the price difference between organic and conventional items have only a weak effect on the probability of buying organic.

The empirical literature addresses a major concern, namely, the motivations of buyers of organic products. A literature review by Hughner et al. (2007) examines 33 studies, all published between 1990 and 2004, on organic purchasing behaviour in the US and various European countries. The researchers find that considerations related to health, product quality and environmental protection constitute the three main reasons for buying organic products. However, there is no consensus on the ranking of these reasons.

More recently, Mondelaers et al. (2009), Griffith and Nesheim (2013), and Kriwy and Mecking (2011) consider health to be the main reason. Abrams et al. (2010) illustrate that consumers associate the organic label with high quality. In contrast, studies by Durham (2007) and Monier-Dilhan and Bergès (2016) indicate that consumers of organic products are primarily preoccupied with environmental considerations. In addition, Monier-Dilhan and Bergès (2016) emphasize that socio-economic characteristics can modify the ranking between motivations related to health and product quality.

\section{Conclusion}

Overall, in recent years, we see the growth of labels in the field of health, the environmentally friendly and so-called 'agro-ecological' products. The emerging markets for 'agroecological' products are still limited to niche markets. We can mention two labels related to this concern: "Haute valeur environnementale", a public environmental certification of farms and products from these farms, and "Bleu, Blanc, Coeur" (BBC), a private label based on a change in practices of animal feeding to improve the health value of products (Magrini et al., 2014; Schmitt et al., 2017).

As we conducted an analysis in the case of public labels according to the type of brands (national brands or store brand) on which they are affixed, it would be informative to carry out the same analysis in a private label framework. A label such as BBC would be an interesting subject of study in terms of willingness to pay and purchasing motivations. Indeed, this private label is affixed to staple products (dairy products, animal products) on national brands, stores brands and local brands. The willingness to pay for the private $\mathrm{BBC}$ label, according to these various supports, would give elements of an answer as to the informative function of the label.

Driven by increasing consumer demand for healthier, safer, and more environmentally friendly food products, the use of food labelling has become increasingly important in recent years. The aim of food labels is to provide information to consumers; nevertheless, the proliferation of labels on a same product reduces this effect and may confuse consumers.

Acknowledgements. The French National Research Agency [grant ANR-15-CE21-0006 'Institutionnalisations des agroécologies'], and the French Occitanie Region and INRA 
[PSDR4 Program] are gratefully acknowledged for their respective financial support.

\section{References}

Abrams KM, Meyers CA, Irani TA. 2010. Naturally confused: consumers' perceptions of all-natural and organic pork products. Agric Hum Values 27(3): 365-374. DOI: 10.1007/s13165-0150109-3.

Bunte F, Van GalenM, Kuiper E, Bakker J. 2007. Limits to Growth in Organic Sales; Price Elasticity of Consumer Demand for Organic Food in Dutch Supermarkets. The Hague, LEI, Report 7.06.20; ISBN/EAN: 978-90-8615-127-1.

Caswell JA, Modjuszka EM. 1996. Using Information Labeling to Influence the Market for Quality in Food Products. Am J Agric Econ 78(5): 1248-53.

Dettmann R, Dimitri C. 2010. Who's Buying Organic Vegetables? Demographic Characteristics of U.S. Consumers. J Food Prod Mark 16(1): 79-91.

Dimitri C, Dettmann R. 2012. Organic food consumers. What do we really know about them? Br Food $J$ 114(8): 1157-1183.

Durham CA. 2007. The impact of environmental and health motivations on the organic share of purchases. Agric Resour Econ Rev 36(2): 304-320.

Griffith R, Nesheim L. 2013. Hedonic methods for baskets of goods. Econ Lett 120: 284-287.

Grunert KG, Hieke S, Wills J. 2014. Sustainability labels on food products: Consumer motivation, understanding and use. Food Policy 44: 177-189.

Hassan D, Monier-Dilhan S. 2006. National brands and store brands: competition through public quality labels. Agribusiness 22(1): 21-30.

Hotaling JM, Cohen AL, Shiffrin RM, Busemeyer JR. 2015. The Dilution Effect and Information Integration in Perceptual Decision Making. PLoS ONE 10(9): e0138481. DOI: 10.1371/ journal.pone.0138481.

Hughner RS, McDonagh P, Prothero A, Clifford J, Shultz CJ, Stanton J. 2007. Who Are Organic Food Consumers? A Compilation and Review of Why People Purchase Organic Food. J Consum Behav 6(2-3): 94-110.6.

Kriwy P, Mecking RA. 2011. Health and environmental consciousness, costs ofbehaviour and the purchase of organic food. Int $J$ Consum Stud 36: 30-37.
Loureiro ML, McCluskey JJ, Mittelhammer RC. 2001. Assessing consumer preferences for organic, eco-labeled, and regular apples. J Agric Resour Econ 26(2): 404-416.

Magrini MB, Charrier F, Duru M. 2014. Une analyse de la niche d'innovation Bleu-Blanc-Cœur. Innov Agronomiques 39: 139161.

Magnusson MK, Arvola A, Koivisto Hursti UK, Aber L, Sjoden PO. 2003. Choice of organic foods is related to perceived consequences for human health and to environmentally friendly behaviour. Appetite 40: 109-117.

McCluskey JJ, Loureiro ML. 2003. Consumer Preferences and Willingness to Pay for Food Labeling: A Discussion of Empirical Studies. J Food Distrib Res 34(3): 95-102.

Mondelaers K, Verbeke W, Van Huylenbroeck G. 2009. Importance of health and environment as quality traits in the buying decision of organic products. Br Food J 111(10): 1120-1139.

Monier-Dilhan S, Bergès F. 2016. Consumers' motivation driving organic demand: between self-interest and sustainability. Agric Resour Econ Rev 45(3): 522-538.

Monier-Dilhan S, Hassan D, Nichèle V, Simioni M. 2009. Organic Food Consumption Patterns. J Agric Food Ind Org 7(2): 1-23. ISSN (Online) 1542-0485. DOI: 10.2202/1542-0485.1269.

O'Donovan P, McCarthy M. 2002. Irish consumer preference for organic meat. Br Food J 104(3/4/5): 353-370. DOI: 10.1108/ 00070700210425778.

Schmitt B, Ferry C, Mairesse G, et al. 2017. The choice of animal feeding system influences fatty acid intakes of the average French diet. OCL. DOI: $10.1051 / \mathrm{ocl} / 2017022$.

Teisl M, Roe B. 1998. The Economics of Labeling: An Overview of Issues for Health and Environmental Disclosure. Agric Resour Econ Rev 27(2): 140-150. DOI: 10.1017/S1068280500006468.

Thompson GD, Kidwell J. 1998. Explaining the Choice of Organic Produce: Cosmetic Defects, Prices, and Consumer Preferences. Am J Agric Econ 80(2): 277-287. DOI: 10.2307/1244500.

Vlaeminck P, Vranken L. 2015. Do labels capture consumers' actual willingness to pay for Fair Trade characteristics? Bioeconomics Working Paper 2015/5. Department of Earth and Environmental Sciences, University of Leuven.

Wier M, Jensen KD, Andersen LM, Millock K. 2008. The Character of Demand in Mature Organic Food Markets: Great Britain and Denmark Compared. Food Policy 33(5): 406-421.

Zepeda L, Li J. 2007. Characteristics of Organic Food Shoppers. $J$ Agric Appl Econ 39: 17-28.

Cite this article as: Monier-Dilhan S. 2018. Food labels: consumer's information or consumer's confusion. $O C L 25(2)$ : D202. 